\title{
A personal reflection on doctoral student progression during the Covid-19 pandemic
}

\author{
Nomathemba Ndlovu \\ Flinders University, Adelaide, Australia
}

Keywords: doctoral student progression; Covid-19.

\section{The challenge}

In 2018, I enrolled as a doctoral student aiming to develop an attendee satisfaction measurement tool for the Zimbabwean exhibition industry. Having survived the upheaval of two international relocations in the first 18 months of my candidature, my progression was threatened by the abrupt Covid-19-induced closure of my university in March 2020. While some universities quickly digitalised their teaching methods and doctoral supervision, universities in Zimbabwe grappled with inequalities and access to affordable and consistent internet connectivity for both staff and students (Taru, 2020). My university did not have the requisite technology and digital tools to facilitate learning or to provide alternatives for administrative meetings that were traditionally held face-to-face.

I also felt uncertain about the future of the exhibition industry itself. Nationwide lockdowns had resulted in the mass cancellation of the annual face-to-face business events in Zimbabwe that I was investigating, and other countries were already re-defining the design and execution of business events in the wake of Covid-19 (Schulz, 2020). These additional factors meant that a delay in submission would affect my research results. With universities in other countries also hamstrung by the lack of capacity to facilitate digital migration (Watermeyer et al., 2021), it was tempting to find comfort in the fact that I was not alone. However, the reality was that, as a self-funded student investigating a rapidly changing industry, remaining in the same institution or extending my candidature were not options. My challenge was how to ensure the timely completion of my doctorate when the technological infrastructure and examination capacities of Higher Education Institutions in Zimbabwe were so heavily compromised. 


\section{The response}

With my current university unable to give me the support I needed to complete my studies, I sought external solutions. The first was to transfer to a university with the technology, tools, infrastructure and reputation to enable me to complete. To identify options, I reached out to my supervisors, as they were at other universities, to see if I could transfer there. I concurrently explored transferring to institutions that fellow $\mathrm{PhD}$ students referred me to. Off this base, I then did further research on the reputation of these institutions to assess how receptive they were to remote students and to see whether they had suitable supervisory staff with expertise in my topic. I then narrowed my search down to those with hassle-free admissions procedures and affordable fee structures. Without understating the hours of careful comparison and deliberation, I used a combination of objective criteria such as global university rankings and the more subjective, but relatable, former student reviews to make the final selection of the university I decided to transfer to.

Second, I reached out to my academic support network. Navigating the transition to a new university showed me that, while I thought I was no stranger to progressing my studies remotely, I had underestimated the need for additional emotional and moral support structures to get me across the finish line. Though prior research has established the relationship between strong social networks and doctoral attrition (Ali and Kohun, 2007), the impact of the pandemic spotlighted the rising importance of writing workshops on student wellbeing (Buckley et al., 2021). Convening a weekly online writing club to connect with fellow students helped me to ward off the overwhelming feelings of isolation and selfdoubt. I also reached out to an even larger online community of scholars on various academic social networking fora and virtual writing rooms to keep me motivated.

Lastly, I strengthened my inner resolve to complete my studies. Indeed, it was risky to change institutions so far into my candidature, and many students would not even consider this course of action. From the research on Motivation and Self Determination Theory (Ryan and Deci, 2000), it stood out that what differentiates students who progress in such times of adversity is the strength of their internal motivation (Rahiem, 2021). These students were resilient, disciplined and goal oriented, propelled by parental, societal or religious expectations to ensure their doctoral progression in the very same environment 
that others found debilitating (Boone et al., 2020). I knew that it would take resilience and drive to continue with my studies and adapt my research to respond to the changes that were taking place in the exhibition industry.

\section{Recommendations}

Adopting the Gibbs (1988) Reflective Learning Cycle and a personal narrative style, I hope that this reflection offers some practical solutions to doctoral students striving to complete their PhDs in the face of the challenges such as those presented by the pandemic. Firstly, I recommend that, if working within their current institution is not facilitating progression, doctoral students should not be afraid to look elsewhere for help. They should use their research skills to find institutions that will support their needs and be bold enough to take the leap if it is necessary. Theories of trans-nationalism and deterritorialisation have been successfully applied in universities to provide innovative technology-based solutions for synchronous and asynchronous doctoral supervision (Brabazon, 2017). Students need no longer be limited to a narrow set of options or fear that they cannot have meaningful engagement and build relationships with their supervisors.

Secondly, I recommend that doctoral students reach out to academic social networks to smoothen the transition to a new institution. During the pandemic, some have grappled with anxiety, feelings of grief, stigmatisation, discrimination, isolation and demotivation, which manifested as mental health concerns and attrition from doctoral programmes (Hamza et al., 2020). In the drive to complete my studies, I did not fully appreciate the toll that adjusting to a new institution would have on me all while juggling caring responsibilities for three young boys who were learning from home, but I drew such strength from the 24-hour availability of the online academic network, and it provided me with a sustainable, holistic support structure.

Lastly, I recommend that students remain committed to knowledge creation in spite of adversity. This may mean finding unconventional solutions or being flexible in adapting their research focus in line with the new reality, if that is what is needed to finish. My resolve to keep going yielded positive outcomes, the highlight being the successful 
completion of my thesis within three years and subsequent graduation. My story shows that, while resilience is an indispensable ingredient of overall success, doctoral progression in a pandemic is hinged on an enabling digital infrastructure and supportive academic networks.

\section{References}

Ali, A. and Kohun, F. (2007) 'Dealing with social isolation to minimise doctoral attrition: a four stage framework'. International Journal of Doctoral Studies, 2, pp.33-49. Available at: https://doi.org/10.28945/56 (Accessed: 20 October 2021).

Boone, S.C., De Charon, L., Hill, M., Preiss, A., Ritter-Williams, D. and Young, E. (2020) 'Doctoral student persistence and progression: a programme assessment', Journal of Applied Research in Higher Education, 12(4) pp.753-765. Available at: https://doi.org/10.1108/JARHE-07-2019-0192 (Accessed: 20 October 2021).

Brabazon, T. (2017) '5 minutes to hell. Time to tell the truth. The disintermediated doctoral student', Fast Capitalism, 14(1). Available at:

http://dx.doi.org/10.32855/fcapital.201701.014 (Accessed: 20 October 2021).

Buckley, C.A., Saetnan, E.R., Gerber, A., Cheetham, J., Price, T.A.R., Kenyani, J. and Greaves, A.M. (2021) 'Impact of writing workshops on doctoral student wellness', Journal of Learning Development in Higher Education, 20 pp.1-24. Available at: https://doi.org/10.47408/jldhe.vi20.593 (Accessed: 1 June 2021).

Gibbs, G. (1988) Learning by doing: a guide to teaching and learning methods. Further Education Unit. Oxford Polytechnic: Oxford.

Hamza, C.A., Ewing, L., Heath, N.L. and Goldstein, A.L. (2020) 'When social isolation is nothing new: a longitudinal study psychological distress during Covid-19 among university students with and without pre-existing mental health concerns', Canadian 
Psychology, 62(1), pp.20-30. Available at:

https://psycnet.apa.org/doi/10.1037/cap0000255 (Accessed: 20 October 2021).

Rahiem, M.D.H. (2021) 'Remaining motivated despite the limitations: university students' learning propensity during the Covid-19 pandemic, Children and Youth Services Review, 120, pp.1-14. Available at: https://doi.org/10.1016/i.childyouth.2020.105802 (Accessed: 1 June 2021).

Ryan, R.M. and Deci, E.L. (2000) 'Self-Determination Theory and the facilitation of intrinsic motivation, social development and well-being', American Psychological Association. 55(1) pp.68-78. Available at: https://psycnet.apa.org/doi/10.1037/0003066X.55.1.68 (Accessed: 20 October 2021).

Schulz, B. (2020) 'Could pandemic permanently change Las Vegas convention industry'. Las Vegas Review-Journal. Available at: https://www.reviewjournal.com/business/conventions/could-pandemic-permanentlychange-las-vegas-convention-industry-2063185/ (Accessed: 20 October 2021).

Taru, J. (2020) Digital tragedy: doing online teaching in Zimbabwe during the pandemic. Available at: https://www.coronatimes.net/digital-tragedy-zimbabwe-pandemic/ (Accessed: 1 June 2021).

Watermeyer. R., Crick, T., Knight, C and Goodall, J. (2021) 'Covid-19 and digital disruption in UK universities: afflictions and affordances of emergency online migration', Higher Education, 81, pp.623-641. Available at: https://doi.org/10.1007/s10734020-00561-y (Accessed: 1 June 2021).

\section{Author details}

Nomathemba Ndlovu is a marketing specialist and PhD graduate at Flinders University, Adelaide, Australia. Her research interests are in customer satisfaction and experience 
design in the exhibition industry. She is committed to disseminating African research paradigms to new audiences. 